\title{
Religiusitas dan Prokrastinasi Akademik Mahasiswa
}

\author{
Hayyinah \\ Universitas Islam Indonesia
}

\begin{abstract}
This study examined the relationship between religiousity and academic procrastination. The proposed hypothesis was that there is a negative correlation between religiousity and academic procrastination. The data were collected using religiosity scale and academic procrastination scale. Subjects of this study were 86 college students from one private university in Yogyakarta, from various study discipline. The hypothesis was tested using Pearson product moment correlation. The study result shows that there is a significant negative correlation between religiousity and academic procrastination $(r=-.748, p<0.01$ ). The more religious the student, the less procrastinator he/ she is in regard with his/ her academic activities.
\end{abstract}

\section{Key Words : Academic procrastination, religiousity}

\section{Pendahuluan}

$\mathrm{M}$ asyarakat Indonesia terkenal dengan tradisi kedisiplinan yang kurang. Hal ini dapat dilihat dari kebiasaan mengulur-ulur waktu baik dalam menjalankan suatu tugas maupun dalam menghadiri sebuah pertemuan. Kebiasaan ini telah menjadi fenomena umum di masyarakat Indonesia sehingga melahirkan istilah umum untuk kebiasaan tersebut yaitu jam karet.. Sikap menunda ini dalam literatur psikologi biasa disebut dengan istilah pro-krastinasi. Tidak hanya di Indonesia karena fenomena ini ternyata juga bukan merupakan hal yang luar biasa di luar negeri. Penelitian dari Bruno (1997) mengungkapkan bahwa ada $60 \%$ individu memasukkan sikap menunda sebagai kebiasaan dalam hidup mereka (Ervinawati, 1999). Penelitian lain dari Hara Marano (2003) memberikan kesimpulan bahwa $20 \%$ individu di luar negeri mengaku bahwa dirinya adalah seorang prokrastinator, bahkan bagi individu prokrastinasi telah menjadi semacam gaya hidup.

Angka persentase keterlambat-an lulus di Universitas Islam Indonesia tahun 2000 mencapai angka 23,08\% (Rumiani, 2000). Data terbaru (2003) yang penulis dapatkan dari Biro Akademik dan Administrasi Kemahasiswaan (BAAK) UII terdapat $29,24 \%$ (5655 dari keseluruhan mahasiswa UII) mahasiswa UII belum dapat menyelesaikan kuliahnya setelah menjalani masa kuliah empat tahun.

Keputusan Mentri Pendidikan Nasional Republik Indonesia Nomor 232/U/2000 tentang Pedoman Penyusunan Kurikulum Pendidikan Tinggi dan Penilaian Hasil Belajar Mahasiswa bab III pasal 5 ayat 1 menyatakan bahwa Sistem Kredit Semester untuk jenjang pendidikan S-1 dijadwalkan untuk delapan 
semester yang dapat ditempuh dalam waktu kurang dari delapan semester atau delapan semester. Artinya bahwa pada dasarnya setiap mahasiswa mampu menyelesaikan kuliahnya dalam jangka waktu delapan semester atau empat tahun. Ketika mahasiswa S-1 telah melewati empat tahun masa studinya maka dapat dikatakan ada indikasi mahasiswa tersebut melakukan prokrastinasi akademik.

Prokrastinasi tidak sesuai terjadi pada mahasiswa di universitas yang mempunyai basis ajaran Islam seperti UII. Karena agama Islam sendiri sangat menganjurkan umatnya untuk selalu menghargai waktu dalam hal apapun termasuk kegiatan-kegiatan akademik. Dalam Al-Qur'an Allah menjelaskan arti pentingnya waktu bagi kehidupan manusia yaitu dalam QS. Al-'Ashr. Ayat-ayat di dalamnya menjelaskan pentingnya waktu bagi kehidupan manusia. Jika manusia hidup tidak memperhatikan waktu yang terus berjalan maka manusia akan mengalami kerugian (Sahil \& Dahlan, 1999). Anjuran-anjuran menghargai waktu juga tercermin dalam perintah-perintah ibadah wajib seperti dalam sebuah hadist yang diriwayatkan oleh $\mathrm{Abu}$ Mas'ud Al-Anshori menceritakan bahwa Nabi Muhammad menganjurkan umatnya untuk selalu menyegerakan sholat ketika telah tiba waktunya (Zabidi, 1997). Cuplikan ayat dan hadist diatas secara implisit berisi tentang anjuran menghindari tindakan-tindakan menunda atau prokrastinasi.

Akan tetapi fakta yang terjadi berkebalikan dengan yang seharusnya. Di Universitas Islam Indonesia yang berbasis pada agama Islam masih banyak mahasiswa yang memperlihat-kan indikasi melakukan prokrastinasi bahkan data memperlihatkan presentase yang semakin meningkat. Sebuah ironi karena agama Islam selalu mengajarkan bahwa manusia hendaknya dalam bersikap, berpikir dan berbuat ber-pedoman pada AlQuran dan Al-Hadist. Namun faktor penting yang perlu diingat adalah bahwa cara pandang individu terhadap keberadaan agama mempengaruhi tinggi atau rendahnya tingkat religiusitas yang pada akhirnya akan membentuk sikap dalam kehidupannya termasuk kehidupan aka-demiknya.

Dari penjelasan di atas dapat dibuat pertanyaan penelitian: benarkah terdapat hubungan antara tingkat religiusitas mahasiswa dengan perilaku prokrastinasi akademik?

\section{Dasar Teori}

Prokrastinasi Akademik. Prokrastinasi berasal dari gabungan kata pro dan crastinate yang dalam bahasa latin disebut dengan crastinus. Pro berarti memajukan, melanjutkan atau lebih menyukai dan crastinate berarti sampai besok.. Jika disambung gabungan kata ini berarti memajukan, melanjutkan atau lebih menyukai melakukan aktivitas dihari kemudian. Istilah ini pertama kali digunakan secara ilmiah oleh Brown \& holzman (1967) untuk menunjuk pada suatu kecenderungan menunda-nunda penyelesaian suatu tugas atau pekerjaan (Rizvi, 1997). Solomon dan Rothblum (1984) menemukan bahwa prokrastinasi secara signifikan berhubungan dengan depresi, keyakinan irasional dan harga diri rendah dan kebiasaan belajar yang buruk (Rumiani, 2000). Burka dan Yuen (1983) serta tokoh lain Sabini \& Silver (1982) juga sependapat bahwa keyakinan yang tidak rasional merupakan faktor yang menghambat kinerja dan menimbulkan perilaku prokrastinasi. Selain itu menurut dua tokoh terakhir juga menyebutkan bahwa prokrastinasi lebih dari sekedar sebuah kecenderungan, melainkan suatu respon mengantisipasi tugas-tugas yang tidak disukai, atau karena tidak memadainya suatu penguatan.

Prokrastinasi didefinisikan secara berbeda-beda oleh tiap-tiap tokoh, namun demikian dapat diambil kesimpulan bahwa prokrastinasi adalah suatu tindakan menunda untuk memulai atau menyelesaikan suatu tugas dengan mengganti dengan aktivitas lain 
yang tidak begitu penting dan cenderung menjadi sebuah kebiasaan terjadi karena kurangnya penguatan atau adanya pikiran irasional sehingga menghambat kinerja individu maupun orang lain dan menimbulkan perasaan tidak enak pada pelakunya.

Prokrastinasi akademik merupakan bentuk coping dari mahasiswa untuk mengatasi stress akademik (Covington \& Omelich, 1991). Sabini \& Silver (dalam Rumiani, 2000), berpendapat prokrastinasi lebih dari sekedar kecenderungan, melainkan suatu respon mengantisipasi tugas-tugas yang tidak disukai, atau karena tidak memadainya suatu penguatan atau keyakinan yang tidak rasional yang menghambat kinerja. Menurut Ferrari dkk (1995) prokrastinasi akademik adalah jenis penundaan yang dilakukan pada jenis tugas formal yang berhubungan dengan bidang akademik misalnya tugas sekolah atau tugas kursus. Prokrastinasi akademik menurut Jeremy Hsieh (2003) dianggap sebagai suatu kecenderunan sifat yang dimiliki oleh pelajar yang sering menghadapi tugas-tugas yang mempunyai batas waktu. Ferrari (1995) mengungkapkan bahwa pada dasarnya prokrastinator sadar bahwa individu menghadapi tugas yang penting dan bermanfaat bagi dirinya tetapi dengan sengaja menunda secara berulang-ulang (kompulsif), hingga muncul perasaan cemas ataupun bersalah (Rizvi, 1998). Pengulangan perilaku prokrastinasi ini menurut Jeremy Hsieh (2003) karena adanya penguatan berupa keberhasilan tugas-tugas yang dilakukan pada saatsaat terakhir.

Dari beberapa teori di atas dapat diambil kesimpulan bahwa prokrastinasi akademik adalah suatu tindakan menunda untuk memulai atau menyelesaikan suatu tugas akademik dengan menggantinya dengan aktivitas lain yang tidak begitu penting dan cenderung menjadi sebuah kebiasaan terjadi karena kurangnya penguatan atau adanya pikiran irasional sehingga menghambat kinerja akademik individu maupun orang lain dan menimbulkan perasaan tidak enak pada pelakunya.

Dari beberapa ciri-ciri yang diungkap para tokoh antara lain Rothblum (Rizvi, 1998), Milgram dkk (1991) Solomon and Rothblum (Rumiani, 2000), Quek (2002), dan Ellis \& Knaus (1997), Ferrary dan Timothy (Marano, 2003) dapat ditarik kesimpulan bahwa secara garis besar ciri-ciri prokrastinator di bidang akademik adalah individu yang melakukan penundaan atau meninggalkan tugas, melibatkan emosi yang tidak menyenangkan seperti perasaan cemas dan perasaan bersalah, dan adanya pikiran-piran irasional seperti perfeksionis dan takut gagal.

Solomon dan Rothblum (Rumiani, 2000) berpendapat ada dua macam prokrastinator yaitu yang pertama adalah The Tense Type, prokrastinator tipe ini seringkali merasakan tekanan yang sama kuat antara keinginan untuk menjadi sukses dan ketakutan akan kegagalan. Yang kedua adalah The Relaxed Type, prokrastinator tipe ini seringkali memandang sisi buruk dari tugas atau pekerjaan mereka dan berusaha melupakannya dengan mencari aktivitas lain yang sifatnya lebih menyenangkan.

Berdasarkan fungsinya Ferrari dkk (1995) dan Bruno (1998) mengungkapkan bahwa prokrastinasi akademik ada dua bentuk yaitu: a. Prokrastinasi fungsional yaitu penundaan pelaksanaan tugas untuk mencari data yang lebih lengkap sehingga tugas yang diker-jakan sempurna.

b. Prokrastinasi disfungsional yaitu penundaan penyelesaian tugas tanpa ada arah yang jelas. Prokrastinasi ini merupakan pro-krastinasi yang tidak berguna.

Berdasarkan uraian diatas dapat disimpulkan bahwa pengertian prokrastinasi akademik dalam penelitian ini mengarah pada prokrastinasi disfungsional.

Dari beberapa faktor penyebab dan yang mempengaruhi terjadinya prokrastinasi yang diungkap para tokoh seperti Birner (1994), Ellis dan Knaus (1997), Ferrari dkk (1995), 
yang tidak begitu penting dan cenderung menjadi sebuah kebiasaan terjadi karena kurangnya penguatan atau adanya pikiran irasional sehingga menghambat kinerja individu maupun orang lain dan menimbulkan perasaan tidak enak pada pelakunya.

Prokrastinasi akademik merupakan bentuk coping dari mahasiswa untuk mengatasi stress akademik (Covington \& Omelich, 1991). Sabini \& Silver (dalam Rumiani, 2000), berpendapat prokrastinasi lebih dari sekedar kecenderungan, melainkan suatu respon mengantisipasi tugas-tugas yang tidak disukai, atau karena tidak memadainya suatu penguatan atau keyakinan yang tidak rasional yang menghambat kinerja. Menurut Ferrari dkk (1995) prokrastinasi akademik adalah jenis penundaan yang dilakukan pada jenis tugas formal yang berhubungan dengan bidang akademik misalnya tugas sekolah atau tugas kursus. Prokrastinasi akademik menurut Jeremy Hsieh (2003) dianggap sebagai suatu kecenderunan sifat yang dimiliki oleh pelajar yang sering menghadapi tugas-tugas yang mempunyai batas waktu. Ferrari (1995) mengungkapkan bahwa pada dasarnya prokrastinator sadar bahwa individu menghadapi tugas yang penting dan bermanfaat bagi dirinya tetapi dengan sengaja menunda secara berulang-ulang (kompulsif), hingga muncul perasaan cemas ataupun bersalah (Rizvi, 1998). Pengulangan perilaku prokrastinasi ini menurut Jeremy Hsieh (2003) karena adanya penguatan berupa keberhasilan tugas-tugas yang dilakukan pada saatsaat terakhir.

Dari beberapa teori di atas dapat diambil kesimpulan bahwa prokrastinasi akademik adalah suatu tindakan menunda untuk memulai atau menyelesaikan suatu tugas akademik dengan menggantinya dengan aktivitas lain yang tidak begitu penting dan cenderung menjadi sebuah kebiasaan terjadi karena kurangnya penguatan atau adanya pikiran irasional sehingga menghambat kinerja akademik individu maupun orang lain dan menimbulkan perasaan tidak enak pada pelakunya.

Dari beberapa ciri-ciri yang diungkap para tokoh antara lain Rothblum (Rizvi, 1998), Milgram dkk (1991) Solomon and Rothblum (Rumiani, 2000), Quek (2002), dan Ellis \& Knaus (1997), Ferrary dan Timothy (Marano, 2003) dapat ditarik kesimpulan bahwa secara garis besar ciri-ciri prokrastinator di bidang akademik adalah individu yang melakukan penundaan atau meninggalkan tugas, melibatkan emosi yang tidak menyenangkan seperti perasaan cemas dan perasaan bersalah, dan adanya pikiran-piran irasional seperti perfeksionis dan takut gagal.

Solomon dan Rothblum (Rumiani, 2000) berpendapat ada dua macam prokrastinator yaitu yang pertama adalah The Tense Type, prokrastinator tipe ini seringkali merasakan tekanan yang sama kuat antara keinginan untuk menjadi sukses dan ketakutan akan kegagalan. Yang kedua adalah The Relaxed Type, prokrastinator tipe ini seringkali memandang sisi buruk dari tugas atau pekerjaan mereka dan berusaha melupakannya dengan mencari aktivitas lain yang sifatnya lebih menyenangkan.

Berdasarkan fungsinya Ferrari dkk (1995) dan Bruno (1998) mengungkapkan bahwa prokrastinasi akademik ada dua bentuk yaitu:

a. Prokrastinasi fungsional yaitu penundaan pelaksanaan tugas untuk mencari data yang lebih lengkap sehingga tugas yang diker-jakan sempurna.

b. Prokrastinasi disfungsional yaitu penundaan penyelesaian tugas tanpa ada arah yang jelas. Prokrastinasi ini merupakan pro-krastinasi yang tidak berguna.

Berdasarkan uraian diatas dapat disimpulkan bahwa pengertian prokrastinasi akademik dalam penelitian ini mengarah pada prokrastinasi disfungsional.

Dari beberapa faktor penyebab dan yang mempengaruhi terjadinya prokrastinasi yang diungkap para tokoh seperti Birner (1994), Ellis dan Knaus (1997), Ferrari dkk (1995), 
Solomon dan Rothblum (dalam Rumiani, 2000) dapat ditarik kesimpulan bahwa ada dua faktor utama yang mempengaruhi pro-krastinasi yaitu :

1. Faktor internal, yaitu faktor yang datang dari dalam diri individu yang ikut membentuk perilaku prokrastinasi. Faktor internal ini terdiri dari lemahnya fisik maupun psikis dan tipe kepribadian individu. Faktor tingkat religiusitas berada pada faktor lemahnya psikis individu, yaitu ketika ketika prokrastinasi terjadi karena motivasi yang rendah, irasional dan malas, tiga sikap ini adalah indikasi rendahnya tingkat religiusitas yang dimiliki individu.

2. Faktor eksternal, yaitu faktor yang datang dari luar diri individu seperti tugas yang terlalu banyak dan menuntut penyelesaian pada waktu yang bersamaan (Bruno dalam Rumiani, 2000). Faktor eksternal yang lain adalah faktor lingkungan dan pola asuh orang tua.

Religiusitas. Tingkat religiusitas merupakan paduan dua kata tingkat dan religiusitas. Tingkat sendiri biasanya diartikan sebagai suatu kadar atau kualitas. Sedangkan religiusitas mempunyai dasar kata religius yang berasal dari bahasa latin yaitu religio. Religio memiliki akar kata religare yang berarti mengikat (Driyakara dalam Taufik, 2002). Konsep religiusitas sendiri dalam literatur psikologi diartikan sebagai hubungan personal yang melibatkan perasaan pasrah dan tergantung serta pengakuan akan adanya kekuatan yang melebihi dirinya sendiri. Fromm (Mutahhari, 1984) menyebutkan bahwa tidak seorang pun didunia ini yang tidak membutuhkan agama. Glock \& Stark (Subandi, 1997) mengatakan bahwa agama adalah sistem simbol, sistem keyakinan, sisitem nilai dan sistem perilaku yang terlembagakan yang semuanya berpusat persoalan-persoalan yang dihayati sebagai sesuatu yang paling maknawi (ultimate meaning). Hendropuspito (Alfisyahr, 2001) mendefinisikan agama sebagai suatu jenis sistem sosial yang dibuat oleh penganut-penganutnya yang berporos pada kekuatan-kekuatan non empiris yang dipercayai dan didayagunakan untuk men-capai keselamatan bagi diri mereka dan masyarakat luas pada umumnya.

Dengan demikian dapat disimpulkan bahwa tingkat religiusitas atau tingkat keberagamaan adalah kadar atau kualitas seberapa dalam individu mengintegrasikan ajaran-ajaran agamanya dalam kehidupannya sehari-hari. Sedangkan tingkat religiusitas dalam penelitian ini adalah lebih khusus pada seberapa dalam individu mampu mengintegrasikan ajaran-ajaran agama tentang penghargaan terhadap waktu dalam kehidupanya. Dalam penelitian religiusitas yang dimaksud adalah religiusitas Islam.

Dari beberapa pendapat para tokoh tentang dimensi agama Islam pada khususnya, penulis memilih pendapat dariAnshari (1987). Karena pendapat dari tokoh ini dapat mencakup semua pendapat para ahli bahwa dimensi Islam secara umum terdiri dari akidah, syari'ah dan akhlak. Dimensi-dimensi tersebut dapat disimpulkan sebagai berikut:

\section{Akidah.}

Yaitu kepercayaan dan keyakinan yang mendalam sehingga melahirkan keimanan kepada Allah yang maha Esa, kepada malaikat, rasul-rasul, kitab-kitab, adanya hari qiamat, dan kepada Qada' dan Qadar. Akidah pada hakekatnya adalah pengaplikasian rukun iman.

\section{Syari'at}

Yaitu suatu aturan-aturan dari Allah yang menjadi sarana bagi manusia sehingga menemukan jalan yang lurus kepada Allah. Syari'at terbagi menjadi dua yaitu muamalat dan ibadah.

a. Muamalat adalah peraturanperaturan Allah tentang hubungan sesama manusia yang meliputi aspek kemasyarakatan, keadilan, akhlak, politik, ekonomi dan keuangan.

b. Ibadah dalam pengertian khusus 
adalah pelaksanaan perintah Allah dan Rosul-Nya seperti Syahadat, sholat, zakat, puasa dan haji. Sedangkan hakekat ibadah adalah ketaatan dan ketundukan secara mutlak kepada Allah. Sehingga segala amal perbuatan manusia yang dilakukan dengan dasar ketaatan dan ketundukan kepada Allah adalah sebuah ibadah.

\section{Akhlak}

Akhlak merupakan perilaku yang telah menjadi pribadi bagi seorang muslim sehingga munculnya secara spontan. Akhlak merupakan buah dari iman yang kuat. Akhlak mulia merupakan tanda dari kesempurnaan iman.

Hubungan Tingkat Religiusitas Dengan Prokrastinasi Akademik. Agama Islam adalah agama yang sangat menganjurkan umatnya untuk selalu menghargai waktu dan bersungguh-sungguh dalam melakukan segala sesuatu Salah satu yang mendukung pernyataan ini adalah QS. Al-'Ashr, ayat-ayat didalamnya menjelaskan pentingnya waktu bagi kehidupan manusia yaitu jika manusia hidup tanpa memperhatihan waktu yang terus berjalan maka manusia akan rugi (Dahlan \& Sahil, 1999). Salah satu hadist yang diriwayatkan Bukhori-Muslim juga menjelaskan betapa berharganya waktu. Dalam hadist tersebut Rasulullah mengingatkan umatnya untuk selalu memanfaatkan lima waktu sebelum datangnya lima waktu sesudahnya yaitu memanfaatkan waktu muda sebelum datangnya waktu tua, lapang sebelum sempit, sehat sebelum sakit, kaya sebelum miskin dan hidup sebelum mati. Rasulullah juga menegaskan bahwa manusia yang hari ini lebih buruk dari pada hari kemarin adalah benarbenar manusia yang rugi (Asqalani, 1998). Anjuran Islam kepada umatnya untuk selalu menghargai dan memanfaatkan waktu sebaikbaiknya juga tercermin dalam perintahperintah ibadah yang selalu dikaitkan dengan keutamaan waktu. Misalnya perintah tentang sholat hadist riwayat Abdullah bin Mas'ud menerangkan bahwasanya pekerjaan yang paling disukai Allah adalah sholat yang tepat pada waktunya. Hadist lain yang diriwayatkan oleh Abu Mas'ud Al-Anshori menceritakan bahwa Nabi Muhammad menganjurkan umatnya untuk selalu menyegerakan sholat ketika telah tiba waktunya (Zabidi, 1997).

Beberapa cuplikan ayat-ayat AI Qur'an dan hadist-hadist di atas secara implisit memberikan gambaran bahwa Islam sangat menganjurkan bahwa dalam hal apapun manusia harus selalu mengindahkan ajaran tentang keutamaan waktu termasuk di dalamnya adalah menghargai waktu-waktu dalam kegiatan akademik. Hal ini dapat disimpulkan bahwa ajaran Islam pada dasarnya membentuk pribadi Muslim yang menghindari prorastinasi termasuk prokrastinasi akademik Namun demikian tidak semua muslim mampu meng-integrasikan hal tersebut dalam kehidupannya. Kemampuan dan ketidak mampuan mengintegrasikan ini yang mempengaruhi tingkat religiusitas dalam diri individu. Sehingga tingkat religiusitas mahasiswa dapat mempengaruhi perilakunya dalam mensikapi waktu-waktu dalam kegiatan akademiknya.

\section{Hipotesis}

Berdasarkan tinjauan pustaka di atas, maka dalam penelitian ini diajukan hipotesis yaitu ada korelasi negatif antara tingkat religiusitas mahasiswa dengan prokrastinasi akademik. Semakin tinggi tingkat religiusitas mahasiswa semakin rendah prokrastinasi akademiknya sebaliknya semakin rendah tingkat religiusitas mahasiswa maka semakin tinggi prokrastinasi akademiknya.

\section{Metode Penelitian}

Sesuai dengan hipotesis yang diajukan, maka dibuat rancangan penelitian sebagai berikut :

1. Variabel bebas: Tingkat religiusitas

2. Variabel tergantung: Prokrastinasi akademik 
Secara khusus karakteristik subjek penelitian adalah sebagai berikut :

1. Mahasiswa fakultas Ekonomi, Teknik Sipil dan Perencanaan, dan Teknik Industri Universitas Islam Indonesia.

2. Aktif dalam perkuliahan pada saat pengambilan data penelitian ini. Aktif di sini artinya adalah ketika pengambilan data ini dilakukan subjek masih tercatat sebagai mahasiswa Ull yang sedang mengambil tugas akhir atau mengambil kuliah dengan disertai praktikum, penulisan makalah, laporan dan tugas akademik lainnya.

3. Menempuh studi lebih dari 4 tahun ( mahasiswa angkatan 1998 dan sebelumnya ) diluar cuti akademik.

Data dalam penelitian ini dikumpulkan dengan menggunakan skala. Ada dua macam skala yang digunakan dalam penelitian ini yaitu Skala Prokrastinasi Akademik yang dalam pelaksanaannya disebut sebagai Skala I. Skala prokrastinasi akademik yang digunakan peneliti merupakan modifikasi dari Skala Prokrastinasi Akademik dari Ervinawati (1999). Skala prokrastinasi dari Ervinawati (1999). Skor tinggi yang diperoleh subjek dari skala ini menunjukkan tingginya prokrastinasi akademik subjek, sebaliknya rendahnya skor yang diperoleh mengindikasikan rendahnya prokrastinasi akademik subjek. Skala kedua adalah skala tingkat Religiusitas yang dalam pelaksanaannya disebut sebagai Skala II. Skala tingkat religiusitas memuat tiga dimensi yaitu aqidah, syariah dan akhlaq. Uji coba terhadap alat ukur Skala Tingkat Religiusitas mahasiswa diperoleh koefisien alpha 0,9144 dan 0,9178 untuk Skala Prokrastinasi Akademik.

Metode analisis statistik yang digunakan untuk menguji hipotesis adalah analisis product moment dari Pearson. Namun jika teknik analisis ini ternyata tidak sesuai dengan data penelitian maka akan digunakan teknik analisis lain yang lebih sesuai. Perhitungan statistik ini dilakukan dengan komputasi melalui bantuan program SPSS 10.0.

\section{Hasil Penelitian}

Uji normalitas dengan One sample Kolmogorov-Sminov diperoleh sebaran normal untuk masing-masing variabel yaitu prokrastinasi akademik ( K-S Z $=0,935 ; p=0,347$ atau $p>0,05$ ) dan untuk tingkat religiusitas mahasiswa (K-S Z $=0,765 ; p=0,602$ atau $p>0,05$ ).

Uji linieritas dengan Analisis Regresi terhadap variabel tingkat religiusitas mahasiswa dan prokrastinasi akademik menunjukkan hasil yang linier tapi terdapat beberapa data pengacau diluar garis linier (Linierity $F=156,512 ; p=0,00$ atau $p<0,05$ dan Deviation from Linearity $F=2,069 ; p=0,10$ atau $p<0,05)$.

Hasil uji asumsi diatas memenuhi syarat untuk uji hipotesis dengan menggunakan teknik korelasi dari Product Moment. Hasil analisis korelasi ini menunjukkan ada korelasi negatif yang sangat signifikan antara variabel tingkat religiusitas mahasiswa dengan prokrastinasi akademik. Hal ini ditunjukkan oleh besarnya koefisien korelasi antara tingkat religiusitas mahasiswa dengan prokrastinasi akademik sebesar $r x y=-0,748 ; p<0,01$ dan memberikan sumbangan efektif sebesar 55,95 $\%$. Tingginya nilai korelasi disebabkan oleh masing-masing variabel saling melengkapi, artinya bahwa variabel tingkat religiusitas mahasiswa disesuaikan dengan variabel prokrastinasi akademik yaitu tentang keutamaan waktu.

Dari hasil uji hipotesis tersebut diatas dapat disimpulkan bahwa hipotesis yang berbunyi "Ada korelasi negatif antara tingkat religiusitas mahasiswa dengan prokrastinasi akademik" diterima. Hasil ini dapat digeneralisasikan pada individu yang mempunyai karakteristik sama dengan subjek dalam penelitian ini.

Hasil pengkategorisasian baik tingkat religiusitas maupun prokrastinasi akademik keduanya berada dalam kategori sedang. Hal ini dapat disimpulkan dari persentase terbanyak dari kedua variabel berada pada 
kategori sedang yaitu untuk tingkat religiusitas mahasiswa $48,84 \%$ atau 42 mahasiswa dari 86 mahasiswa, sedangkan untuk variabel prokrastinasi akademik $44,19 \%$ atau sebanyak 38 mahasiswa dari keseluruhan jumlah mahasiswa yang menjadi subjek penelitian yaitu 86 . Hasil pengkategorisasian ini tidak sesuai dengan data objektif yang didapatkan, hal ini dipengaruhi oleh faktor peraturan akademik yang mengikat mahasiswa yang menjadi salah satu pemicu lamanya masa studi mahasiswa.

Tabel diatas menjelaskan bahwa tidak ada perbedaan tingkat religiusitas dan prokrastinasi akademik antar angkatan dan terdapat perbedaan antar fakultas dalam hal tingkat religiusitasnya, namun dalam hal prokrastinasi akademik tiga fakultas tersebut tidak terdapat perbedaan.

\section{Pembahasan}

Uji hipotesis yang telah dilakukan dengan teknik korelasi Product Moment dari Pearson memberikan hasil adanya korelasi negatif yang sangat signifikan antara variabel Tingkat Religiusitas Mahasiswa dengan variabel Prokrastinasi Akademik. Artinya bahwa semakin tinggi tingkat religiusitas mahasiswa maka semakin rendah prokrastinasi akademiknya, sebaliknya semakin rendah tingkat religiusitas mahasiswa maka semakin tinggi prokrastinasi akademik yang dilakukan. Korelasi negatif ini ditunjukkan oleh nilai koefisien korelasi $r$, koefisien korelasi yang diperoleh sebesar $r=-0,748$ yang memberikan sumbangan korelasi sebesar $55,95 \%$. Hasil penelitian ini dapat digeneralisasikan pada subjek lain yang mempunyai karakteristik yang sama dengan subjek dalam penelitian ini.

Nilai negatif pada angka korelasi menunjukkan bahwa ada hubungan yang berbanding terbalik yaitu tingginya tingkat religiusitas mahasiswa diikuti dengan rendahnya prokrastinasi akademik dan sebaliknya tingginya angka prokrastinasi akademik diikuti rendanya tingkat religiusitas mahasiswa. Hal ini sesuai bahwa tingginya tingkat religiusitas akan membentuk sikap yang positif seperti disiplin waktu, motivasi kerja yang tinggi dan lebih rasional. Sikapsikap positif ini yang yang menghindarkan individu dari tindakan prokrastinasi khususnya dalam penelitian ini adalah prokrastinasi akademik sehingga masa studi yang ditempuh pun relatif singkat. Sebaliknya rendahnya tingkat religiusitas akan membentuk sikap negatif seperti senang melakukan penundaan, motivasi kerja rendah dan lebih irasional. Sikap-sikap negatif ini yang akhirnya membentuk tindakan prokrastinasi termasuk prokrastinasi akademik dan menjadi salah satu faktor lamanya masa studi mahasiswa.

Prokrastinator akademik secara garis besar mempunyai ciri-ciri antara lain melakukan penundaan atau meninggalkan tugas, melibatkan emosi yang tidak menyenangkan seperti perasaan cemas dan perasaan bersalah, dan adanya pikiran-piran irasional seperti perfeksionis dan takut gagal, kelambanan dalam menyelesaikan tugas, kesenjangan waktu antara rencana dan kinerja intelektual serta mengerjakan aktivitas lain yang lebih menyenangkan (Schwounberg, dalam Ferrari 1995). Tingginya tingkat religiusitas mahasiswa akan memacu tingginya motivasi, kesungguhan dan pemanfaatan waktu yang efektif bagi mahasiswa. Sikap ini akan memacu mahasiswa untuk sesegera mungkin dan dengan kesungguhan dan motivasi yang tinggi untuk mengerjakan dan menyelesaikan segala sesuatu yang harus mereka lakukan, khususnya dalam hal ini adalah pekerjaan-pekerjaan atau tugastugas akademik. Sikap yang seperti ini juga secara signifikan akan menjauhkan emosiemosi yang tidak menyenangkan seperti kecemasan dan perasaan bersalah. Tingginya tingkat religiusitas juga akan menimbulkan kepasrahan dan keikhlasan yang mendalam yaitu ketika telah berusaha, bersungguhsungguh dan memanfaatkan waktu sebaik mungkin maka selanjutnya adalah hak Allah 'Azza wa jalla untuk menentukan hasil, 


\section{Kategori Skor Variabel Tingkat Religiusitas}

\begin{tabular}{llllc}
\hline Kategori & \multicolumn{1}{c}{ Rumus } & Skor & F & $\%$ \\
\hline $\begin{array}{l}\text { Sangat } \\
\text { Rendah }\end{array}$ & $\mathrm{x}=\mathrm{m}-1,2 \mathrm{SDh}$ & $\mathrm{X}=61,934$ & 11 & 12,79 \\
Rendah & $\mathrm{m}-1,2 \mathrm{SDh}<\mathrm{x}=\mathrm{m}-0,6 \mathrm{SDh}$ & $61,934<\mathrm{x}=69,452$ & 10 & 11,63 \\
Sedang & $\mathrm{m}-0,6 \mathrm{SDh}<\mathrm{x}=\mathrm{m}+0,6 \mathrm{SDh}$ & $69,452<\mathrm{x}=84,488$ & 42 & 48,84 \\
Tinggi & $\mathrm{M}+0,6 \mathrm{SDh}<\mathrm{x}=\mathrm{m}+1,2 \mathrm{SDh}$ & $84,488<\mathrm{x}=92,006$ & 15 & 17,44 \\
Sangat & $\mathrm{m}+1,2 \mathrm{SDh}<\mathrm{x}$ & $\mathrm{x}>92,006$ & 8 & 9,30 \\
Tinggi & & & & \\
\hline Total & & & & \\
\hline
\end{tabular}

\section{Kategori Skor Variabel Prokrastinasi Akademik}

\begin{tabular}{lllll}
\hline Kategori & Rumus & Skor & F & $\%$ \\
\hline $\begin{array}{l}\text { Sangat } \\
\text { Rendah }\end{array}$ & $\mathrm{x}=\mathrm{m}-1,2 \mathrm{SDh}$ & $\mathrm{x}=57,668$ & 8 & 9,30 \\
Rendah & $\mathrm{m}-1,2 \mathrm{SDh}<\mathrm{x}=\mathrm{m}-0,6 \mathrm{SDh}$ & $57,668<\mathrm{x}=65,054$ & 15 & 17,44 \\
Sedang & $\mathrm{m}-0,6 \mathrm{SDh}<\mathrm{x}=\mathrm{m}+0,6 \mathrm{SDh}$ & $65,054<\mathrm{x}=79,826$ & 38 & $\mathbf{4 4 , 1 9}$ \\
Tinggi & $\mathrm{M}+0,6 \mathrm{SDh}<\mathrm{x}=\mathrm{m}+1,2 \mathrm{SDh}$ & $79,286<\mathrm{x}=87,212$ & 18 & 20,93 \\
Sangat & $\mathrm{m}+1,2 \mathrm{SDh}<\mathrm{x}$ & $\mathrm{x}>87,212$ & 7 & 8,14 \\
Tinggi & & & & \\
\hline Total & & & 86 & 100 \\
\hline
\end{tabular}

Analisis Anova

\begin{tabular}{lll}
\hline Variabel & Tingkat religiusitas & Prokrastinasi akademik \\
\hline $\begin{array}{l}\text { Angkatan } \\
(<1996,1997,1998)\end{array}$ & $f=0,443 ; p(0,644)>0,05$ & $f=0,863 ; p(0,426)>0,05$ \\
Fakultas (FE,FTI,FTSP) & $f=3,326 ; p(0,041)<0,05$ & $f=2,135 ; p(0,125)>0,05$ \\
\hline
\end{tabular}


sehingga mahasiswa terhindar dari pikiranpikiran irasional. Hal-hal yang demikian secara umum dapat menjadi prediktor ketepatan waktu mahasiswa dalam menyelesaikan segala sesuatu termasuk ketepatan waktu dalam menempuh masa studinya.

Dari kategorisasi yang telah dilakukan diketahui bahwa tingkat religiusitas mahasiswa termasuk dalam kategori sedang dapat dilihat dari jumlah skor subyek yang berada pada kategori sedang paling banyak $(48,84 \%)$ dibandingkan dengan kategori lainnya. Demikian juga pada prokrastinasi akademik, subjek penelitian sebagian besar $(44,19 \%)$ berada dalam kategori sedang. Hasil tidak sesuai dengan data objektif bahwa prokrastinasi akademik mahasiswa tinggi. Kesenjangan ini disebabkan antara lain oleh faktor sistem dan peraturan yang mengikat mahasiswa yang menjadi salah satu pemicu lamanya masa studi. Misalnya di FTI pelaksanaan Kerja Praktek (KP) tidak diperbolehkan untuk dilaksanakan pada perusahaan-perusahaan yang berada di wilayah Yogyakarta sehingga para mahasiswa yang melakukan kerja praktek harus dilakukan diluar kota Yogyakarta, peraturan ini bagi mahasiswa mengganggu dan menunda kegiatan akademik yang lain, sehingga mahasiswa harus menunggu sampai benarbenar mempunyai waktu luang untuk mengerjakan KP. Contoh lain dari sistem peraturan yang mendukung lamanya masa studi mahasiswa adalah peraturan fakultas yang menyediakan beberapa mata kuliah hanya pada semester-semester tertentu saja sehingga mahasiswa yang harus mengulang mata kuliah tersebut harus menunggu sampai semester yang menyediakan mata kuliah tersebut tiba.

Hasil uji hipotesis tambahan adalah bahwa antara mahasiswa angkatan 1998, 1997, dan <1996 Fakultas Ekonomi, Teknik Industri dan Teknik Sipil dan Perencanaan tidak terdapat perbedaan dalam perilaku prokrastinasi akademik maupun tingkat religiusitasnya. Artinya bahwa antara ma- hasiswa-mahasiswa angkatan 1998, 1997 dan $<1996$ mempunyai kecenderungan yang sama dalam melakukan prokrastinasi akademik dan dalam tingkat religiusitasnya. Sedangkan antara mahasiswa fakultas Ekonomi, Teknik Industri dan Teknik Sipil dan Perencanaan terdapat perbedaan dalam hal tingkat religiusitasnya yaitu fakultas Teknik Sipil dan Perencanaan mempunyai tingkat religiusitas paling tinggi disusul fakultas Teknik Industri dan fakultas Ekonomi. Namun dalam hal prokrastinasi akademik ketiga fakultas tersebut tidak didapatkan perbedaan..

\section{Kesimpulan}

Hasil uji hipotesis dari data penelitian menunjukkan bahwa tingkat religiusitas mahasiswa memiliki korelasi negatif yang sangat signifikan dengan prokrastinasi akademik. Pengkategorisasian menunjukkan subjek penelitian memiliki tingkat religiusitas dan tingkat prokrastinasi akademik dalam kategori sedang. Analisis tambahan menghasilkan ada perbedaan tingkat religiusitas antara mahasiswa Fakultas Ekonomi (FE), Teknik Industri (TI) dan Teknik Sipil dan Perencanaan (FTSP), di mana FTSP memiliki tingkat religiusitas yang paling tinggi dibandingkan dua fakultas yang lain. Namun dalam hal perilaku prokrastinasi akademik mahasiswa ketiga fakultas tersebut memiliki kesamaan. Ditinjau dari angkatan tidak terdapat perbedaan antara angkatan $<1996$, 1997 dan 1998 dalam tingkat religiusitas dan prokrastinasi akademiknya.

\section{Saran}

Berdasarkan hasil penelitian yang diperoleh, maka penulis ingin mengemukakan beberapa saran :

\section{a. Bagi Subjek Penelitian}

Tingkat religiusitas dan tingkat prok- 
rastinasi akademik subjek penelitian yang tergolong dalam kategori sedang mengisyaratkan harus ditingkatnya pemahaman dan pengamalan subjek penelitian terhadap ajaranajaran agamanya sehingga dapat meningkatkan motivasi subjek penelitian untuk menyelesaikan segala tugas akademik. Sehingga hal yang menjadi kendala dalam kemajuan pendidikan dalam hal ini penundaan yang dilakukan mahasiswa tidak dilakukan lagi.

\section{b. Bagi Pihak Fakultas}

Pertama, menimbang kembali peraturanperaturan yang telah dibuat agar tidak mejadi salah satu pemicu lamanya masa studi mahasiswa.

Kedua, menjalin kerjasama yang baik dengan mahasiswa untuk menciptakan suasana yang religius dilingkungan kampus karena lingkungan dapat mempengaruhi secara signifikan terhadap perubahan individu didalamnya. Dengan demikian jika hal ini dapat dicapai dengan baik maka sesuai dengan hasil penelitian ini bahwa tingkat religiusitas mahasiswa akan mengurangi perilaku prakrastinasi akademik. Sehingga perilaku prokrastinasi dapat dihilangkan dari tiga fakultas dalam penelitian ini pada khususnya dan lingkungan UII pada umumnya.

\section{c. Bagi Peneliti Selanjutnya}

Bagi peneliti selanjutnya disarankan untuk memperhatikan faktor-faktor lain yang dapat mempengaruhi dan mendukung terjadinya prokrastinasi akademik baik di Universitas Islam Indonesia mapun di lingkungan pendidikan yang lain, misalnya faktor tingkat religiusitas yang dilihat secara umum dan yang merupakan bentuk penghayatan dan bukan pengetahuan.

\section{Daftar Pustaka}

Alfisyahr, S. 2001. Hubungan Antara Religiusitas Dengan Kecenderungan Agresi Pada Siswa SMU Muhammadiyah II Yogyakarta. Skripsi (tidak diterbitkan). Yogyakarta: Fakultas Psikologi Universitas Islam Indonesia.

Anshari, E.S. 1987. IImu Filsafat dan Agama. Surabaya: PT. Bina Ilmu.

Asqalani, I.H.A. 1998. Nasahaihul Ibad. Jakarta: Pustaka Amani.

Azwar, S. 1997. Sikap Manusia dan Pengukuranya. Yogyakarta: Pustaka Pelajar.

Bruno, F.J. 1998. Stop Prcrastinating ! (terjemahan). Jakarta: PT. Gramedia.

Covington \& Omelich. 1991. Stress and Coping. http : // al I. successcenter.ohio-state.edu. 12/4/03.

Dahlan, Z., Sahil, A. 1999. Qur'an Karim dan Terjemahan Artinya. Yogyakarta: UII Press.

Ellis, a \& Knaus , W.J. 1997. Over-coming Procrastination. http : //www. carleton. ca/ tpychyl/tips.html 13/4/03

Ervinawati, E. 2000. Harga Diri dan Prokrastinasi akademik pada Mahasiswa UII. Skripsi (tidak diterbitkan). Yogyakarta: Universitas Islam Indonesia.

Ferrari, J.R; Johnson, J.L \& McCown, W. G. 1995. Procrastination and Task Avoidance: Theory, Research and Treatment. New York:Plenum Press. 
Forum Silaturohim Pendampingan Agama Islam- Jama'ah Shalahuddin. 1993. Meniti Jalan Islam. Yogyakarta: UGM.

Hadi, S. 1996. Statistik 2. Cetakan 12. Yogyakarta: Andi Offset.

Hsieh, J. 2002. Procrastinating students flock to web for papers. http : // al I. successcenter. Ohio - state.edu 28 / $3 / 03$

Marano, H. 2002. Tomrrow... Tomorrow: Why We Procrastinate.http:// all.successcenter.ohio-state.edu/28/ $3 / 03$

Milgram, N. 1991. Procrastination dalam Dulbecco, R. Encyclopedy of Human Biology. http://www.ucalgary.ca/ -steel/procrastinus/define.html 28/3/ 03

Muttahari, M. 1984. Manusia dan Agama. Bandung: Mizan.

Nashori, F. 1997. Manusia Sebagai Homo Religiosus. Jurnal Psikologika, Hal. 35, No. 3, tahun 11. Yogyakarta:
Fakultas Psikologi Universitas Islam Indonesia.

Queik. 2002. Overcoming Procrastination. http:// all. successcenter.ohiostate.edu/. 1/3/03

Rizvi, A., Prawitasari, J.E \& Soetjipto, H.P. 1997. Pusat Kendali dan Efikasi Diri sebagai Prediktor Prokrastinasi Akademik Mahasiswa. Jurnal Psikologika, Hal. 51-66, No. 3, tahun 11. Yogyakarta: Fakultas Psikologi Universitas Islam Indonesia.

Rumiani. 2000. Prokrastinasi Akademik Ditinjau dari Motivasi Berprestasi dan Stress Pada Mahasiswa. Skripsi (tidak diterbitkan). Yogyakarta : Universitas Islam Indonesia

Subandi. 1997. Tema-tema Pengalaman Beragama Pengamal Dzikir. Jurnal Psikologika, Hal. 7-18, No. 3 Vol. II tahun 1997.

Zabidi, A. 1997. Hadist-Hadist Sahih. Bandung: Mizan. 